\title{
Property Law in the New Romanian Civil Code ${ }^{1}$
}

\author{
Szilárd SZTRANYICZKI \\ Sapientia Hungarian University of Transylvania \\ Department of Legal Studies \\ sztranyiczkisz@yahoo.com
}

\begin{abstract}
Taking into account the recent change in Romanian civil legislation, we consider the present scientific material very useful for an overview of this institution under the auspices of the New Civil Code. The national legal provisions set clear, therefore, that the property is divided into two institutions, the public property and the private property. Property classification is very important in this form for us to understand the legal nature and the applicable regime for each type of property. Moreover, the property right, either private or public, has an elite regulation in most European laws, but also in universal laws the respect for it and the guarantee of this right can be also found in the fundamental human rights, in the international treaties, and in the constitutions of different nations. We will try, therefore, to offer a brief overview of the new Romanian legislation in the mentioned field, which is already harmonized with European legislation, the result being the New Romanian Civil Code. We believe that the interpretation should be considerably more extensive, but - pragmatically - we will try to capture the main theoretical and practical features to denote the importance of this institution.
\end{abstract}

Keywords: property, property rights, private property, public property, definition, human rights, special incapacities, legal inalienabilities, constitution, international treaties, movables, immovables, physical entities, legal entities, the state, territorial-administrative units, citizens, foreign citizens, expatriates, pre-emption, resolvable property, annullable property, conditioned property, common property, periodical property

\section{Notion of the Right to Private Property}

Property right is closely linked to patrimony, and in the Romanian doctrine it has been proposed that it is also linked to the owner. The New Civil Code (in the following: NCC) recognizes the priority of private property in relation to public property. This is the reason why Art. 554, paragraph 2 stipulates that if

1 The New Civil Code was adopted in Romania on 1 October 2011. 
the law does not state the contrary the applicable dispositions of private property rights are also applied to public property rights, but only to the degree that these dispositions are compatible with the latter. In the NCC, private property rights are regulated by art-s 555-692, and public property rights by art-s 858-875.

The standard definition of the right to private property is found in the NCC Art. 555, paragraph 1: private property is the right of the owner to possess, use, and dispose of goods exclusively, absolutely, and perpetually, within the limits defined by the law.

This definition, in our conception, is far from being complete (Stătescu, Bîrsan 1980: 31-32). This is why, in defining property, one must start from the legal concept of the right to property, comprised of the prerogatives (attributes) recognized by the law, on the one hand; on the other hand, these prerogatives are exercised without the intervention of other persons, who form a general, passive, and undefined subject. In addition, there are many situations in which a part or all of these attributes are exercised by some person other than the owner, on the basis of another real right derived from the right to property. For example, the usufructuary, to whom the law grants attributes of possession and use of the object of the usufruct, or the superficiary, who can also exercise the attributes of material and legal disposition beyond the attributes of possession and use.

To the question of how an owner differs from other persons entitled to parts of a property, who exercise some of the attributes belonging to the owner, the response is that the owner of the property exercises his/her attributes in his/her own power and in his/her own interest. In his/her own power means that he/she is not legally subordinated to anybody, except the law, and all the other persons exercising real rights are obliged to know this. In his/her own interest means that the exercise of the right to property is done exclusively to satisfy the property owner's own interests, without obligations toward other people.

When we define the right to private property, we focus, first and foremost, on the general definition of property. The form of private property is stipulated in Art. 136.5 of the Constitution and Art. 552 of the NCC. In the context of putting our civil rights on new foundations, with the adoption and implementation of the NCC, private property has become dominant (not only in a theoretical sense) because the goods that make up private property are in a general civil sphere, which make them overwhelmingly important in ensuring the permanent material needs of the members of society. The dominating force of private property, in contrary to public property, derives from the fact that it is found in commerce, and the healthier and more responsive its sphere is, the greater the development of a competitive economy of society, satisfying general and particular interests. In contrast, public property is outside the civil sphere, and within the system of property private property is the norm and public property, through its strict system, constitutes an exception. The constitutional guarantee and protection of private property is also 
found in Art. 44, paragraph 1 of the fundamental law, which stipulates that the right to private property, as well as debts and claims against the state, are guaranteed; and in Art. 44, paragraph 1 of the Constitution, according to which private property is protected and guaranteed equally by the law, no matter the titleholder.

Private property, besides the Constitution and NCC, is also regulated in a series of normative acts, organic and ordinary laws, including Law No 18/1991 of the Land Registry, Law No 7/1996 regarding Cadastre and Real Estate Registry, etc. The most complete regulation of the legal system of the right to private property is in the NCC.

As far as terminology is concerned, from the evolving legislative conceptions and the attributes of property law, the following notions are used: private property, particular property, and the state's or the territorial-administrative units' private domain.

The given definition leads to the exercise of the three attributes, in one's own right and own interest, regardless of whether they are exercised directly or through persons whose benefit certain real rights have been granted to (usufruct, location, superficies, etc.) (Sabău-Pop 2000: 45).

Starting from the legal conception of the right to private property and appreciating the specific position of the owner, one can define the right to private property as a real right that confers upon the title holder the attributes of possession, use and disposition of a good, appropriated in private form; attributes which he/she can exercise in their totality, in his/her own power and own interest, in an exclusive, absolute, and perpetual manner, respecting the material and legal limits defined by the law. Exercising private property is realized through the correspondence that must exist between legal capacity and subjective right.

The conclusion drawn from this definition is that it takes into consideration the legal content of the right to property, consisting of the totality of attributes recognized as belonging to the owner.

In the modern age, there is a new method of analysis that tends to show that private property is not easily confined to the simple stature of a subjective law; even though this may be complex, it fulfils a real social function. This new dimension justifies the restrictions on the exercise of property right, which today are more and more numerous, emphasizing the tendency that property ceases to be an intangible and absolute subjective right in order to become, along with family, a supple and orderly institution, in the service of the community.

At the same time, one notes a concerted universal or regional action of some organizations in order to adopt some norms for the protection of human rights, including the right to property. In addition to the Universal Declaration of Human Rights, adopted by the UN in 1948, of special importance is the European Convention of Human Rights and Fundamental Liberties adopted by the member countries of the European Council in 1950, which came into effect in 1950 and in our country 
on June $20^{\text {th }} 1994$. According to the additional Protocol No 1, any physical or legal entity has the right of having his/her goods protected. No one can be deprived of his/her property unless for the purpose of public utility and according to the conditions stipulated in the law and the general principals of international law (European Convention on Human Rights, as amended by Protocol No 11: 2001, 27).

On the other hand, returning to the idea of the social function of property, the second paragraph of the same text states that the dispositions are not of a nature to fulfil the rights of sovereign states to adopt laws that they deem necessary to regulate the use of private property goods, according to general interest.

Called upon to consider the applicability of a regulation of the European Council, the Luxembourg Court decided that fundamental rights, property rights in particular, cannot generate absolute prerogatives, only prerogatives limited by their social functions. Such restrictions respond effectively to the Union's general interests, and so they cannot constitute an exaggerated and intolerable intervention, which could posit the existence of the guaranteed right (Court of Justice of the European Community, 1991, Cause Georg Von Deetzen C. Hauptzollampt Oldenburg: 1989, 2).

\section{Subjects to the Right to Private Property}

From the definition, in principle, it follows that the right to private property can belong to any subject of the law: physical entities, legal entities, the state, and territorial-administrative units.

Similarly, according to Art. 553, paragraph 4 of the NCC, goods, objects of private property, no matter the title holder, are and will stay in the civil sphere even though the law does not provide for it. They can be expropriated, can be the object of judicial execution, and can be acquired in any way stipulated in the law. Therefore, immovables (land and constructions) in private ownership are in the general civil sphere, so they can be expropriated and acquired in any way regulated by the law (convention or contract, legal and testamentary inheritance, accession, usucaption, and court order). In the case of private property land since it is part of the civil sphere -, the right to property is transmissible in its entirety or in its dependent parts.

Exceptions to the norm - that property right can be acquired absolutely by physical and legal entities - are those stipulated expressly in the law. There are cases of special incapacities and legal inalienabilities:

a) Special incapacities:

- foreign citizens, expatriates, and legal persons can acquire the right to private ownership of land - in the limited conditions stipulated by Art. 44, paragraph 2 of the Constitution and Law No 312/2005. 
As far as private ownership of land is concerned, Art. 44, point 2 of the Constitution recognizes the possibility of acquiring property rights over land by foreign citizens and expatriates, but only under conditions resulting from Romania's joining the EU and other international treaties that Romania is part of, based on reciprocity, according to the conditions stipulated by organic law. According to this constitutional text, which is repeated by Art. 6, paragraph 1 of Law No 312/2005, in addition to the fulfilment of special conditions, the general condition of reciprocity ${ }^{2}$ in such treaties is obligatory. So far, Romania has not signed such an international treaty, which allows certain foreign nationals and expatriates to acquire land in Romania.

Law No 312/2005, referring to the acquisition of private property right over lands by foreign citizens, expatriates, and other foreign legal entities, grants the possibility of acquisition of property rights over lands to these categories of people, delayed until Romania's joining the European Union (1 January 2007), and under the conditions of international treaties that Romania is part of.

According to Art. 5, paragraph 1 of Law No 312/2005, the citizen of a member state, the expatriate with residency in a member state or in Romania, and the legal entity constituted according to the legislation of a member state can acquire property right over agricultural lands, forests, and forest-lands after 7 years from the date of Romania's joining the European Union. This special limitation will be implemented on 1 January 2014, when the seven-year period stipulated in the legal text above expires.

Exceptions to this general rule are:

I) farmers, who carry out independent activities and are either citizens of member states or expatriates with domicile in a member state, who establish their residency in Romania, or expatriates with domicile in Romania. These persons acquire the property right over agricultural lands, forests, and forestlands according to the same conditions applicable to Romanian citizens, from the date of Romania's joining the European Union. The state of being a farmer must be proved with issued documents, according to each case, either by the suitable authorities of the member state or the state of origin, or by the certificate issued by the Romanian Ministry of Agriculture, Forests, and Rural Development. All these persons have the obligation to not change the designation of the agricultural

2 The reciprocity condition has many exceptions in international law. As a rule, international treaties have a synallagmatic character, establishing reciprocal rights and obligations for both parties. However, in the context of the constitutional text, reciprocity becomes obligatory. In international law, the reciprocity condition has a second meaning: certain problems can be resolved through agreement of states or on the basis of reciprocity. Namely, reciprocity is a principle of solution, of solving the problems between the states, in the absence of a treaty. Art. 6, paragraph 1 of Law No 312/2005 states the condition of reciprocity: The foreign citizen, expatriate, and legal entity belonging to tertiary states cannot acquire the right to private ownership of land in more favourable conditions than those applicable to a citizen of a member state and to the legal entity constituted according to the legislation of a member state. 
lands, forests, and forestlands before the expiration of the seven-year period, stipulated in Art. 5, paragraph 1, Law No 312/2005.

II) the citizen of a member state who is not a resident in Romania, the expatriate who is a non-resident in Romania with domicile in a member state, and the legal entity who is a non-resident constituted according to the legislation of a member state, can acquire property right over land for the purpose of secondary residency and secondary headquarters, respectively, at the fulfilment of 5 years from Romania's joining the European Union (1 January 2012).

- foreign citizens and expatriates can acquire the right to private ownership of land through legal inheritance, according to the conditions stipulated in Art. 44, paragraph 2 of the Constitution.

Therefore, through legal inheritance, foreign citizens can acquire the right to private property. Per a contrario, such individuals cannot acquire the right to private property in case of testamentary inheritance. Taking into consideration the principles guiding the application of civil law in time, foreign citizens and expatriates can acquire the right to private ownership of lands in Romania from the effective date of the Revision Law of the Romanian Constitution No 429/2003, but only if the succession case in reference to which the legal inheritance is exercised was opened after this date.

b) Cases of legal inalienability:

- requirement of the authentic form of legal acts disposing of immovable goods (lands and constructions);

- land acquired according to the criteria in Art. 19, paragraph 1, art-s 21 and 43 of Law No 18/1991 of the Land Registry cannot be expropriated through agreements inter vivos for a period of ten years from the beginning of the year following the one in which the property was registered, under the sanction of absolute voidness of the expropriation act, and the acquired apartments by tenants or title holders of apartment contracts (apartments which are not restituted in nature to the former owners or their heirs) cannot be expropriated for a period of ten years from the date of purchase, according to Art. 9, last paragraph of Law No 112/1995;

- exercise of the right to pre-emption (Deak 1992: 34-43, Beleiu 1992: 3-15) in selling movables and immovables. The right to pre-emption was defined in specialty books as that subjective civil right recognized by law to certain titleholders, which gives priority to such individuals to purchase unincorporated agricultural areas, seriatim, and under other conditions prescribed by law (Chelaru 1998: 19-25). Evidently, the cited author only consulted the provisions of Law No 18/1991 of the Land Registry valid at that time. Art. 1730, paragraph 1 of the NCC defines the right to pre-emption as, according to the conditions established by the law or contract, the title holder of the right to pre-emption, called preemptor, can purchase a good with priority. Therefore, the right to pre-emption 
is a priority right to purchase a good, according to the conditions established by the law or through convention. At the same time, taking into consideration legal regulation, we can define the right to pre-emption as a right with a temporary character, established by the law or through a convention of the parties, in which certain title holders called pre-emptors have the priority right to buy movables or immovables.

The right to pre-emption must be viewed as a possibility conferred upon a person to purchase a good with precedence over any other buyer. This priority materializes through the exercise of the right to private property following the consent agreement of the parties, which allows the characterization of this institution as extra-contractual.

The right to pre-emption is provided by art-s 1730-1740 of the NCC, and its domain of application extends to all movables and immovables. Titleholders of the legal right to pre-emption are the following:

I) in the case of lands that belong to the forest registry in private property, these can be sold respecting, seriatim, the pre-emptive right of co-owners or neighbours (Art. 1746 of NCC);

II) in the case of agricultural goods, tenant farmers have the right to pre-emption over the rented agricultural goods (Art. 1849 of NCC).

Art. 1732 of NCC regarding the conditions of the exercise of the right to preemption provides that the seller is obliged to notify the pre-emptor immediately regarding a contract signed with a third party. Notification can also be done by the third party. It includes the first and last name of the seller, the description of the good, the responsibilities incumbent upon him/her, the terms and conditions of the sale, as well as the place where the good is situated. The pre-emptor can exercise his/her right by communicating to the seller his agreement to sign a selling contract, together with the specification of the price to the seller. The right to pre-emption is exercised, in the case of movable sales, in a period of at most 10 days, and in the case of immovable sales in a period of at most 30 days. In both cases, the time period is calculated from the pre-emptor's communication of the notification.

As regards the effects of the exercise of pre-emption (Art. 1733 of the NCC), the contract of sale is considered final between the pre-emptor and seller under the conditions included in the contract with the third party, and the latter contract is terminated retroactively. However, the seller is responsible to the third person for good faith for an eviction resulting from the exercise of pre-emption.

The NCC, inspired by French legislation, opts for the possibility of the exercise of the pre-emptive right following the consent agreement between the seller and the third party, under the form of a retraction. The contract is signed between the owner and the third party, subsequently the title holder of the pre-emptive right (co-owner or neighbour, in the case of lands belonging to the Forest Registry); 
then, the tenant farmer, regarding rented agricultural goods, or the renter, when signing a new lease, is notified about the existence of the translative property act. These persons may exercise their rights, substituting themselves for the buyer from the initial contract, assuming in this way all the rights and obligations of the third party, as in the case of a cession (Malaurie, Aynès, and Gautier 2001: 132). We have reservations about this solution chosen by the Romanian legislature. We consider that the chosen option - the exercise of the right to pre-emption following the finalization of legal acts - will not prove its practical utility. The procedure needed to exercise this right is much more useful and pragmatic if it is carried out before the consent agreement on a good, which better serves the effectiveness of the civil sphere.

\section{Legal Forms of Property Rights}

The right to property is presented as pure and simple or affected by various forms. (Stătescu, Bîrsan 1980: 177-179, Beleiu 1994: 154).

The pure and simple right to property is the right belonging to a single person and is acquired by its owner actually, surely, and irrevocably; its existence in the owner's patrimony does not depend on a future event or circumstance which could terminate it through resolution, revocation, or annulment.

The right to property affected by various modalities exists when its general characteristics are modified; its existence in the patrimony of a person is uncertain, another person exercises his/her attributes, or it belongs alike and at the same time to two or more subjects of the law, and each is entitled to a part of this right.

The pure and simple right to property is the norm, and the right to property affected by various forms is the exception.

Clause 555, paragraph 2 of the NCC specifies that: Under the law, the right to private property is susceptible to various modalities and partitions, according to the case in question. One must note, however, that not only the right to property is susceptible to modifications but all the other main/principal real rights.

The Romanian Civil Law recognizes the following forms of property rights: a) resolvable property, b) annullable property, and c) common property. Some authors (Josserand: 1938: 1009-1014), due to the common characteristics of the resolvable and annullable properties, include both in the larger notion of conditioned property.

Resolvable property exists when the transfer of the right was done through a legal act affected by a resolutionary condition. It is also called revocable property. Let us suppose a person sells a good to another: under the condition that if he/ she has a baby, that good should revert to his/her or his/her heirs' patrimony. In 
the example given, the acquirer is an owner under resolutory condition, and the transmitter is an owner in suspension.

Conditional obligation is defined by Art. 1399 of the NCC: an obligation affected by condition is an obligation whose efficacy or termination depends on an uncertain future event, and the condition is resolutory when its fulfilment determines the termination of the obligation (Art. 1401, paragraph 1 of the NCC). The fate of the right to property depends on the fulfilment or non-fulfilment of the uncertain future event. Theoretically, we are in the presence of the pendente conditione: the good that is the object of expropriation belongs to two owners. Therefore, the expropriator has a right to property that is subject to a suspensive condition and the acquirer has a right to property that is subject to a resolutory condition. The acquirer's resolutory condition has the effects of a suspensive condition toward the transmitter, and vice versa. Namely, the acquirer is the actual and temporary owner; his right is made uncertain by the resolutory condition, and the transmitter has the possibility of becoming the owner of the property in question if the suspensive condition materializes.

Resolvable property can result from the convention of the parties; there are two cases when it results from the law. The first situation is regulated by Art. 1022, paragraphs 1-2 of the NCC: the promise of donation is revoked by right if one of the revocation cases for ingratitude appears anterior to its execution, as prescribed by Art. 1023 of the NCC (if the beneficiary attempted to harm the donor, a person close to him/her, or, knowing that others intend to harm the donor, did not notify him/her; if the beneficiary is guilty of penal acts, cruelty, or serious injuries to the donor; if the beneficiary unjustifiedly refuses to ensure food to the donor in need, limited to the actual worth of the donated good and considering the condition of the good at the time of donation). Similarly, the promise of donation is revoked by right when, anterior to its execution, the material situation of the promisor has deteriorated to the degree that the execution of the promise has become excessively onerous for him/her or the promisor has become insolvent. The second situation is regulated by Art. 1031 of the NCC, which stipulates that donations between married couples are revocable only during marriage, rendering uncertain the property rights of the beneficiary spouse.

Annullable property is a legal form of the right to property, which appears in the situation when the transfer of property from one person to another is done on the basis of a legal act struck down by relative (annullable) annulment. The relative annulment of the legal act is very important, that is, it should focus on the interests of the parties who signed the agreement, and therefore contain the possibility for the expressed or tacit confirmation of those who are interested to invoke annulment.

In the case of a relative annulment of the legal act, the action taken for its court annulment is prescribed by the law (in the NCC) within the time frame of three years. 
The one who acquired the right to property is in an uncertain situation until the fulfilment of the prescribed term because the success of the annulment action will retroactively terminate his/her title.

We need to mention that if the annullable act is expressly confirmed by the one who could have invoked its annullability during this time period, the act's fragility disappears, and the right to property is definitely consolidated.

These are also the two effects of annullable property.

If the nullified act is confirmed by the one entitled to an annulment action, the right is consolidated without the right to return or oppose the annulment motive to a possible forced execution. The confirmation effects do not take place in the case of third parties, with the exception of universal successors or simple contract creditors.

The second effect takes place when the annulment motive is invoked and the title of the annullable property is annulled.

Common property is considered to be the most important form of the right to property. In the case of this property, the prerogatives of common law belong to two or more titleholders together and simultaneously. According to the provisions of Art. 632, paragraph 1 in the NCC, common property is of two kinds: a) common property based on quota (co-ownership) and b) common property in joint ownership.

Common property based on quota or co-ownership is a form of common property where a good belongs to more titleholders simultaneously and it is, at the same time, undivided in its entity. Each co-owner has an ideal, abstract, mathematical share determined, which is expressed by fraction or percentage. The right of each owner meets the rights of the other owners as regards every part of the good.

The right to property in joint ownership is a form of common property in which a good belongs undividedly, indivisibly to all titleholders, who own it together. According to Art. 667, joint ownership can result from the law or on the basis of a legal act.

The main characteristic of the right to common property in joint ownership is that the title holders of this right do not know either the extent of their property rights or the share they are entitled to or the goods each possesses in their entity.

Periodical property was introduced into the NCC (art-s 687-692) as an absolute novelty. It is possible for the right to private property to have more titleholders, each exercising successively and repetitively his/her attribute of use over an immovable or movable in equally or unequally determined intervals of time. This practical application generally appeared in the domain of real estate investments, especially in the case of vacation homes.

The general system of periodical property is applied obligatorily in the absence of some special regulations. In other words, whenever the characteristic elements 
of periodical property are present, another legal system of private property cannot be chosen. This solution is provided by Art. 687 of NCC, according to which the dispositions of the present chapter (periodical property) are applied in the absence of a special regulation. Per a contrario, if a legal derogatory regime has been established, it will be applied.

The following characteristics result from the notion of periodical property:

- the right to property belongs to many title holders;

- the attribute of use is exercised successively and repetitively by the title holders in equally or unequally determined intervals of time;

- its objects can be any kind of movables or immovables.

According to the provisions of Art. 688 of the NCC, periodical property is formed on the basis of a legal act, in which the dispositions regarding the land registry are applied accordingly. The legal act can be a bequest or a convention. For example: the parties agree to acquire the right to periodical property for the building of a house; the parties agree to acquire periodical property right over the purchase of a certain good; the parties agree to transform co-ownership into periodical property.

\section{The Right to Public Property}

The right to public property is a property right belonging to the state or to a territorial-administrative unit over goods, which, in their nature or by law, are of public use or interest, under the condition that they be acquired through one of the ways prescribed by the law; the prerogatives of this right are exercised as public right, which is inalienable, imprescriptible, and unseizable (exempt from seizure).

The normative acts regulating the right to public property provide for the titleholders of the right in a limiting manner. Accordingly, Art. 136.2 of the Constitution states that public property is protected and guaranteed by law and belongs to the state and territorial-administrative units. Similarly, Art. 1 of Law No 213/1998 stipulates that the right to public property belongs to the state or territorial-administrative units. Art. 860, paragraph 1 of NCC distinguishes between public property goods of the national, county, or local public domain. In reference to public property lands, Art. 4, paragraph 2 of Land Registry Law No 18/1991 prescribes that the public domain can be of national interest, in which case the property, in the system of public rights, belongs to the state, or of local interest, in which case the property, also in the system of public rights, belongs to the towns, townships, cities, or counties.

One concludes from the legal texts above that the titleholders of the right to public property are: 
a) the state, over goods that are part of the national public domain;

b) territorial administrative units - townships, towns, cities, and counties -, over goods that are part of the local or county public domain and belong to territorial administrative units as legal entities of public right.

In this context, one must emphasize that no other subject of public or private right can be the titleholder of the right to property over goods that constitute the public domain. Such legal entities acquire, by law, the right to administer, use, lease, or rent the goods that are part of the public domain, which are real rights. However, these rights cannot be mistaken for the exercise of attributes of the public property right.

Art. 863 of NCC principally regulates cases of acquisition of public property rights. These are:

a) public acquisition carried out according to the law;

b) expropriation for public utility according to the law;

c) donation or bequest, accepted according to the law, if the good, through its nature or through the disposer's will, becomes of public use or interest;

d) contract with a gratuitous clause, if the good, through its nature or through the acquirer's will, becomes of public use or interest;

e) transfer of a good from the private domain of the state into its public domain, or from the private domain of a territorial-administrative unit into its public domain, according to the law;

f) other ways established by the law.

The inclusion of goods in the public domain can be accomplished through means of civil, administrative, or penal law.

It is important to note that the inclusion in the public or private domain of the state or the territorial-administrative units depends on the nature, distinction, or characteristics of the goods in question.

\section{References}

BELEIU, Gh. 1992. The Right to Preemption Regulated by Law No 18/1991 of the Land Registry. Bucharest: Dreptul 12.

1994. Romanian Civil Law. Introduction in Romanian Civil Law, Subjects of Civil Law. Bucharest: Şansa.

CHELARU, E. 1998. The Right to Preemption Regulated by Law No 54/1998. Bucharest: Dreptul 8.

COURT OF JUSTICE OF THE EUROPEAN COMMUNITY. 1991. Cause Georg Von

Deetzen C. Hauptzollampt Oldenburg. 1989. Bulletin CJCE 18(1).

DEAK, Fr. 1992. The Right to Preemption. Bucharest: Dreptul 7. 
EUROPEAN CONVENTION ON HUMAN RIGHTS, as amended by Protocol no 11. 2001. Strasbourg: European Treaty Series 5.

JOSSERAND, L. 1938. Cours de droit civil positiv français. Paris, Recueil Sirey: Tome premiere.

MALAURIE, I.-AYNÈS, L.-GAUTIER, P.-Yv. 2001. Cours de droit civil, Les contrats spéciaux civils et commerciaux. Paris, Cujas: 14-e edition.

SABĂU-POP, I. 2000. Acquiring the Right to Property. Bucharest: Accent. STĂTESCU, C.-BÎRSAN, C. 1980. Civil Law. The General Theory of Real Rights. Bucharest: Editura Universității din Bucureşti. 